\title{
Cardiopulmonary Functions of School Children in Oil-Spilled and Gas-Flared Niger- Delta and Rural-Riverine Lagos Communities
}

\author{
*AWETO, HA; SARO-BAKPO, MA; AIYEGBUSI, AI \\ Department of Physiotherapy, Faculty of Clinical Sciences, College of Medicine, University of Lagos, PMB 12003, Idi-Araba, Lagos, \\ Nigeria. \\ *Corresponding Author Email: awetohappiness@gmail.com; haweto@unilag.edu.ng \\ Tel: +2348028964385
}

\begin{abstract}
Cardiopulmonary functions can be influenced by chemicals from flared toxic gases and oil spillages. This study determined and compared the cardiopulmonary functions of six hundred apparently healthy primary school children (338 male and 262 female) aged 6 to 9years recruited from two communities. Three hundred of them were dwellers of Kegbara-Dere (an oil-spilled and gas-flared community) in Rivers State while the other 300 were recruited from Makoko (a rural-riverine community) in Lagos State. Their parents/guardian gave informed consent before their basic anthropometric parameters were obtained. Their cardiovascular and pulmonary parameters were also measured. Data was analysed using Statistical Package for Social Sciences (SPSS) 21.0. The mean values of the systolic blood pressure (SBP), diastolic blood pressure (DBP), Heart Rate (HR) and Rate Pressure Product (RPP) for the oil-spilled/gas-flared Niger-Delta and the rural-riverine Lagos Communities were $112.99 \pm 9.99 \mathrm{mmHg}$ and $111.12 \pm 9.27 \mathrm{mmHg}$, $73.63 \pm 8.41 \mathrm{mmHg}$ and $74.05 \pm 6.85 \mathrm{mmHg}, 98.41 \pm 14.33 \mathrm{bpm}$ and $95.56 \pm 12.07 \mathrm{bpm}$ and $11187.45 \pm 2247.98 \mathrm{mmHg} . \mathrm{bpm}$ and $10655.00 \pm 1832.86 \mathrm{mmHg} . b p m$ respectively. The mean values of the Forced Expiratory Volume in one second $\left(\mathrm{FEV}_{1}\right)$, Forced Vital Capacity (FVC) and Peak Expiratory Flow Rate (PEFR) were $1.02 \pm 0.26 \mathrm{~L}$ and $1.25 \pm 0.23 \mathrm{~L}, 1.10 \pm 0.26 \mathrm{~L}$ and $1.34 \pm 0.25 \mathrm{~L}$ and $1.58 \pm 0.49 \mathrm{~L} / \mathrm{s}$ and $2.24 \pm 0.61 \mathrm{~L} / \mathrm{s}$. Independent t-test analysis showed statistically significant differences between the mean values of the SBP $(p=0.017), \operatorname{HR}(p=0.009), \operatorname{RPP}(p=0.002), \mathrm{FEV}_{1}(\mathrm{p}=0.001), \mathrm{FVC}(\mathrm{p}=0.001)$ and PEFR ( $\mathrm{p}=0.001$ ) of the children from the two communities. Children living in the oil-spilled and gas-flared Niger-Delta community have a significantly higher cardiovascular parameters and a significantly lower Pulmonary functions when compared with those in the rural-riverine Lagos community.
\end{abstract}

DOI: https://dx.doi.org/10.4314/jasem.v23i8.17

Copyright: Copyright $\left({ }_{0} 2019\right.$ Aweto et al. This is an open access article distributed under the Creative Commons Attribution License (CCL), which permits unrestricted use, distribution, and reproduction in any medium, provided the original work is properly cited.

Dates: Received: 28 June 2019; Revised: 18 August 2019; 29 August 2019

Keywords: Cardiovascular parameters, Pulmonary functions, Gas flaring, Oil spillage, Particulate matter, Petroleum hydrocarbons.

Cardiopulmonary variables gives a measure of the performance of the respiratory and circulatory system and some of them include; Forced Expiratory Volume in one second $\left(\mathrm{FEV}_{1}\right)$, Forced Vital Capacity (FVC), Peak Expiratory Flow Rate (PEFR), Respiratory Rate (RR), Heart Rate (HR), Systolic Blood Pressure (SBP), Diastolic Blood Pressure (DBP), Mean Arterial Pressure (MAP) and Rate Pressure Product (RPP) (Queensland Health, 2012). Cardiopulmonary functions are influenced by age, gender, height, weight, altitude and physical activity and environmental activities such as those related to flaring of gases (Vedala et al., 2013). Gas Flaring is the burning of unwanted gas through a pipe also called a flare. Flaring is a means of disposal used when there is no means of transporting the gas to market and the operator cannot use the gas for another purpose. The gas is therefore, let off into the open environment (United Nations Environmental Programme (UNEP), 2011). Similarly, oil spillage is the accidental release of crude or refined oil products into the environment. Hydrocarbons can be found in spilled oil. They are formed by the decay of organic substances trapped within sedimentary rocks. High temperatures and pressure convert the trapped matter into hydrocarbons and depending on the length of the carbon chain, can occur in gas, liquid or solid form (UNEP, 2011). Liquid hydrocarbon found in nature is also referred to as crude oil. Petroleum hydrocarbons can penetrate the human body when contaminated air is breathed in or contaminated water is drunk or used for bathing (UNEP, 2011). Research carried out in Ogoniland of the Niger-Delta, has revealed the presence of extractable petroleum hydrocarbons (EPHs) in surface waters up to $7420 \mu \mathrm{g} \mathrm{L}-1$, drinking water wells showed up to $42200 \mu \mathrm{g} \mathrm{L}-1$, and benzene up to $9000 \mu \mathrm{g} \mathrm{L}-1$, more than 900 times the World Health Organisation (WHO) guidelines (Olof and Jonas, 2013). According to a World Bank study on the environment in year 2000, gas flaring in the Niger 
Delta, particularly in Rivers and Bayelsa States, releases about 35 million tons of carbon dioxide and 12 million tons of methane each year (Ovuakporaye et al., 2016). About 815,000 metric tons per year of air pollution load exists in both states from hydrocarbon related activities (Ovuakporaye et al., 2016). Petroleum hydrocarbons especially those of the Benzene, Toluene, Ethylbenzene and Xylenes (BTEX Group) have also been shown to affect respiratory health (Mckenzie et al., 2012; Emam, 2016). Gases such as sulphur dioxide, nitrogen oxide, carbon dioxide, carbon monoxide, methane, dioxins, hydrogen fluoride, chlorine, benzene and very small dust particles called particulate matter (PM) of less than 10 micrograms, that are emitted from crude oil and gas flaring activities can get deep into the lungs, cause its irritation and that of the respiratory tracts, ignite acute lung swelling and affects the ability to breathe among other harmful and toxic effects on respiratory health (WHO, 2012; Emam, 2016, Ovuakporaye et al., 2016). Air pollution resulting from oil and gas is associated with millions of premature deaths recorded globally and about $25 \%$ of which are estimated to be respiratory in nature (Silva et al., 2013; Lelieverd et al., 2015).

Particulate matter which is one of the substances in flared gas have been demonstrated to have short and long term impacts on lung functions in children without known lung disease (Castro et al., 2009; Weinmayr et al., 2010). It is a mixture of liquid droplets and extremely small particles composed of organic and inorganic compounds (Diette et al., 2007). Particulate matter of less than $2.5 \mu \mathrm{g}\left(\mathrm{PM}_{2.5}\right)$ can penetrate deep into the gas-exchanging regions of the lungs (Laden et al., 2000). It has been associated with adverse impacts on lung functions in children (Anderson et al., 2012). It causes lung inflammation and mucous secretion by acting on airway epithelial cells and alveolar macrophages and may lead to airway remodeling (Churg et al., 2003). Castro et al (2009) found that PM was associated with a $0.34 \mathrm{~L} / \mathrm{min}$ decrease in PEFR in 118 school children in Rio de Janeiro. Also, higher concentration of PM measured on the morning prior to lung function testing, was associated with a marginal decrease in $\mathrm{FEV}_{1}$ and $\mathrm{FVC}$ in 163 healthy Austrian school children (Moshammer et al., 2006). The study by Gauderman (2004) showed that Children exposed to the highest $\mathrm{PM}_{2.5}$ concentrations had an approximately $80 \mathrm{~mL}$ lower $\mathrm{FEV}_{1}$ than children exposed to the lowest level of PM. Another study of healthy 10-year-old children in Norway showed that exposure to PM was associated with a $58-66 \mathrm{~mL} / \mathrm{sec}$ lower PEFR (Oftedal et al., 2008). In a study by Ovuakporaye et al (2016) on the impact of gas flaring on cardiopulmonary parameters in some states of the Niger Delta, gas flaring was found to increase blood pressure, pulse rate and respiratory rate of about 1008 participants. Ekpeyong et al (2012) conducted a cross-sectional survey to assess the respiratory health effect of city ambient air pollutants on workers in Uyo Metropolis in the NigerDelta and observed that there was a significant relationship between exposure to ambient air pollution and respiratory malfunctions.

The health impacts of oil spillage and gas flaring is always recounted but very few studies have objectively evaluated the extent of the impact on the affected communities especially those in the Niger Delta region of Nigeria. The United Nations Environmental Programme's report on Ogoni Land, which now serves as recast to the extent of health risks the children of the region are faced with, has recommended a yearly health review for the region. To this end, this study compared the cardiopulmonary functions of children in an oil-spilled and gas-flared Niger-Delta community with those in a Lagos rural riverine community.

\section{MATERIALS AND METHODS}

Methods: Six hundred apparently healthy primary school children (338 male and 262 female) aged 6 to 9 years were recruited for this study. Three hundred of them were dwellers of Kegbara-Dere (an oil-spilled and gas-flared community) in Gokana Local Government Area of Rivers State while 300 were recruited from Makoko (a rural-riverine community) in Yaba Local Government Area of Lagos State. These children would have lived in these communities for a minimum of one year. Excluded from the study were children who were suspected of having cardiovascular and pulmonary ailments or those who have history of these ailments as well as obesed children. Ethical approval was obtained prior to the study from the Health Research and Ethics Committee of the Lagos University Teaching Hospital (LUTH) Idi-Araba, Lagos (Health Research Committee Assigned No: ADM/DCST/HREC/APP/1554).

Procedure for data collection: An introductory letter was obtained from the Department of Physiotherapy, School of Postgraduate studies, University of Lagos and taken to the state schools' management boards for approval. Upon approval of the state schools' management boards (Lagos State Government Approval Letter No: LSUBEB/GEN/677/X/1/125), introductory letters were taken to the Heads/Principals of the study schools for their approval. The aims, objectives, and procedures of the study were carefully explained to them and the lists of the pupils/students whose ages ranged from 6-9 years were obtained. These pupils/students were screened for eligibility based on the inclusion and exclusion criteria of the 
study. Informed consent forms and screening forms were given to the eligible pupils/students to take home home to their parents/guardians for signing. The next day, those whose parents/guardian gave their informed consent, had their basic anthropometric parameters (height and weight) measured using height meter and weighing scale respectively. Other demographic data such as age and gender were obtained and recorded. This was necessary because the data obtained from the two communities were similarly matched in age and gender. Thereafter, the cardiopulmonary parameters such as SBP, DBP, HR, RR, FEV ${ }_{1}, \mathrm{FVC}$ and PEFR of the participants were measured and recorded. Data was analysed using Statistical Package for Social Sciences (SPSS) 21.0.

\section{RESULTS AND DISCUSSION}

There were $178(59.3 \%)$ and $160(53.3 \%)$ males in the oil-spilled/gas-flared Niger-Delta community and rural-riverine Lagos Community respectively (Figure 1). The mean age of participants was $7.56 \pm 1.13$ years (7.55 \pm 1.13 years for the oil-spilled/gas-flared NigerDelta community and $7.57 \pm 1.13$ years for the ruralriverine Lagos Community). Table 1 shows the age distribution of participants. One hundred and fortytwo $(23.7 \%)$ of the participants were six years old while $164(27.3 \%)$ were nine years old. The mean height, weight and body mass index (BMI) of the participants were $1.22 \pm 0.07 \mathrm{~m} \quad(1.22 \pm 0.70 \mathrm{~m}$ for participants of the oil-spilled/gas-flared Niger-Delta community and $1.23 \pm 0.08 \mathrm{~m}$ for participants of the rural-riverine Lagos community), $20.42 \pm 3.13 \mathrm{~kg}$ (19.95 $\pm 3.21 \mathrm{~kg}$ for participants of the oil-spilled/gasflared Niger-Delta community and $20.89 \pm 2.99 \mathrm{~kg}$ for participants of the rural-riverine Lagos community) and $13.65 \pm 1.53 \mathrm{~kg} / \mathrm{m}^{2}\left(13.59 \pm 1.49 \mathrm{~kg} / \mathrm{m}^{2}\right.$ for participants of the oil-spilled/gas-flared Niger-Delta community and $13.65 \pm 1.53 \mathrm{~kg} / \mathrm{m}^{2}$ for participants of the rural-riverine Lagos community). The mean values of the DBP, SBP, HR, Rate Pressure Product (RPP) and Mean Arterial Pressure (MAP) for participants of the oil-spilled/gas-flared Niger-Delta and the ruralriverine Lagos Communities are shown on Table 2. They were $112.99 \pm 9.99 \mathrm{mmHg}$ and $111.12 \pm$ $9.27 \mathrm{mmHg}$ for SBP and $11187.45 \pm 2247.98$ mmHg.bpm and $10655.00 \pm 1832.86 \mathrm{mmHg} . b p m$ for RPP for participants of the oil-spilled/gas-flared Niger-Delta and those of the rural-riverine Lagos Communities respectively. Similarly, the mean values of the FEV 1 , FVC, PEFR and RR are shown also on Table 2. They were $1.02 \pm 0.26 \mathrm{~L}$ and $1.25 \pm 0.23 \mathrm{~L}$ for $\mathrm{FEV}_{1}$ and $1.58 \pm 0.49 \mathrm{~L} / \mathrm{s}$ and $2.24 \pm 0.61 \mathrm{~L} / \mathrm{s}$ for PEFR for participants of the oil-spilled/gas-flared NigerDelta and the rural-riverine Lagos Communities respectively.

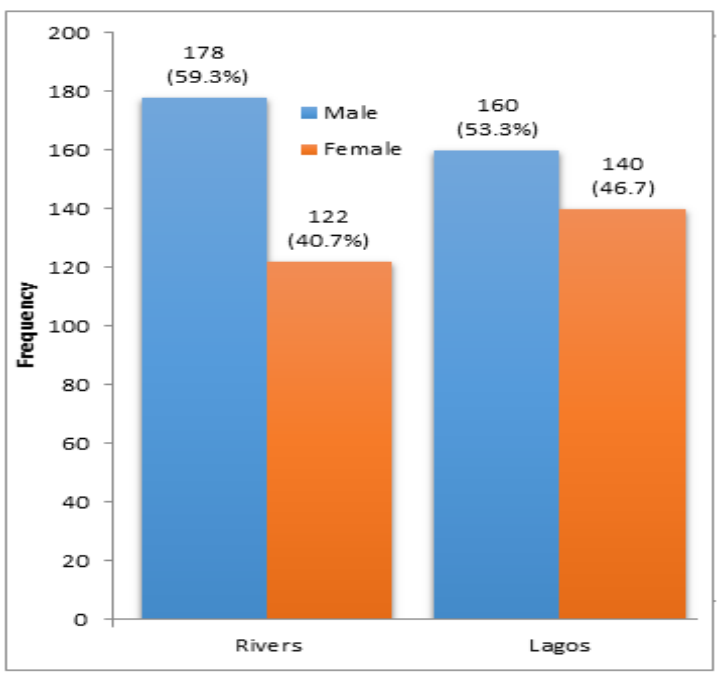

Fig 1: Sex distribution of Rivers State (Niger-Delta) and Lagos State Participants

Table 1: Age distribution of the participants

\begin{tabular}{lllll}
\hline Variables & $\begin{array}{l}\text { Rivers } \\
(\mathrm{n}=300)\end{array}$ & $\begin{array}{l}\text { Lagos } \\
(\mathrm{n}=300)\end{array}$ & $\begin{array}{l}\text { All } \\
\text { participants } \\
(\mathrm{n}=600)\end{array}$ & $\begin{array}{l}\text { Perce } \\
\text { ntage } \\
(\mathrm{n}=\%)\end{array}$ \\
\hline Age & & & & \\
(years): & 72 & 70 & 142 & 23.7 \\
6 & 72 & 72 & 144 & 24.0 \\
7 & 76 & 74 & 150 & 25.0 \\
8 & 80 & 84 & 164 & 27.3 \\
9 & 300 & 300 & 600 & 100.0 \\
Total & & & & \\
\hline
\end{tabular}

Independent t-test analysis showed statistically significant differences between the mean values of the SBP $(p=0.017), H R(p=0.009), \operatorname{RPP}(p=0.002), F_{1}$ $(p=0.001), \operatorname{FVC}(p=0.001)$ and PEFR $(p=0.001)$ of participants in the two communities (Table 2). Independent t-test analysis showed significant differences only between the mean values of the DBP $(p=0.004)$ as well as between the mean values of the $\mathrm{FEV}_{1}, \mathrm{FVC}$ and PEFR $(\mathrm{p}<0.05)$ of male participants in the two communities (Table 3). Independent t-test analysis showed significant differences between the mean values of all the cardiovascular parameters $(p<0.05)$ as well as between the mean values of the $\mathrm{FEV}_{1}, \mathrm{FVC}$ and PEFR $(\mathrm{p}<0.05)$ of female participants in the two communities (Table 4). These results show that participants in the oil-spilled and gas-flared NigerDelta community had higher cardiovascular parameters (SBP, HR, RPP and MAP) and lower pulmonary functions parameters $\left(\mathrm{FEV}_{1}, \mathrm{FVC}\right.$ and PEFR) than their counterparts in the rural-riverine Lagos community. Differences in matched values were significant for SBP, HR, RPP, $\mathrm{FEV}_{1}, \mathrm{FVC}$ and PEFR $(\mathrm{p}<0.05)$ indicating that children resident in the oil-spilled and gas-flared community had higher cardiovascular parameters (SBP, HR and RPP) and reduced pulmonary functions $\left(\mathrm{FEV}_{1}, \mathrm{FVC}\right.$ and PEFR) than the rural-riverine Lagos community. 
Table 2: Comparison of Cardiopulmonary parameters of participants in both Communities

\begin{tabular}{lllll}
\hline Variable & \multicolumn{2}{c}{ Mean \pm S.D } & t-value & p-value \\
& Rivers & Lagos & & \\
\hline DBP (mmHg) & $73.63 \pm 8.41$ & $74.05 \pm 6.85$ & -0.160 & 0.873 \\
SBP (mmHg) & $112.99 \pm 9.99$ & $111.12 \pm 9.27$ & 2.390 & $0.017^{*}$ \\
HR (bpm) & $98.41 \pm 14.33$ & $95.56 \pm 12.07$ & 2.635 & $0.009^{*}$ \\
RPP (mmHg.bpm) & $11187.45 \pm 2247.98$ & $10655.00 \pm 1832.86$ & 3.180 & $0.002^{*}$ \\
MAP (mmHg) & $86.97 \pm 8.34$ & $86.30 \pm 7.21$ & 0.876 & 0.381 \\
RR (bpm) & $25.99 \pm 3.85$ & $25.64 \pm 1.91$ & 1.439 & 0.151 \\
FEV (L) & $1.02 \pm 0.26$ & $1.25 \pm 0.23$ & -11.445 & $0.001^{*}$ \\
FVC (L) & $1.10 \pm 0.26$ & $1.34 \pm 0.25$ & -11.657 & $0.001^{*}$ \\
PEFR (L/s) & $1.58 \pm 0.49$ & $2.24 \pm 0.61$ & -14.696 & $0.001^{*}$ \\
\hline
\end{tabular}

KEY: : "significant at p<0.05; DBP: Diastolic Blood Pressure; SBP: Systolic Blood Pressure; HR: Heart Rate; RPP: Rate Pressure Product; MAP: Mean Arterial Pressure; FEV : Forced Expiratory Volume in one second; FVC: Forced Vital Capacity; PEFR: Peak Expiratory Flow Rate; RR: Respiratory Rate

Table 3: Comparison of Cardiopulmonary parameters of Male participants in both Communities

\begin{tabular}{|c|c|c|c|c|}
\hline \multirow[t]{2}{*}{ Variable } & \multicolumn{2}{|c|}{ Mean \pm S.D } & \multirow[t]{2}{*}{ t-value } & \multirow[t]{2}{*}{ p-value } \\
\hline & Rivers & Lagos & & \\
\hline DBP (mmHg) & $72.80 \pm 8.30$ & $75.25 \pm 7.17$ & -2.913 & $0.004 *$ \\
\hline SBP (mmHg) & $112.33 \pm 9.89$ & $110.74 \pm 9.13$ & 1.535 & 0.126 \\
\hline HR (bpm) & $95.29 \pm 12.44$ & $96.45 \pm 10.14$ & -0.942 & 0.347 \\
\hline RPP (mmHg.bpm) & $10759.53 \pm 1953.11$ & $10749.38 \pm 1671.36$ & 0.051 & 0.959 \\
\hline MAP (mmHg) & $86.39 \pm 8.91$ & $86.91 \pm 7.37$ & -0.583 & 0.560 \\
\hline RR (bpm) & $25.75 \pm 4.13$ & $25.23 \pm 1.79$ & 1.516 & 0.131 \\
\hline FEV1 (L) & $1.07 \pm 0.24$ & $1.28 \pm 0.23$ & -8.225 & $0.001 *$ \\
\hline FVC (L) & $1.16 \pm 0.24$ & $1.37 \pm 0.25$ & -8.010 & $0.001 *$ \\
\hline $\operatorname{PEFR}(\mathrm{L} / \mathbf{s})$ & $1.70 \pm 0.47$ & $2.36 \pm 0.65$ & -10.498 & $0.001 *$ \\
\hline
\end{tabular}

\begin{tabular}{|c|c|c|c|c|}
\hline \multirow[t]{2}{*}{ Variable } & \multicolumn{2}{|c|}{ Mean \pm S.D } & \multirow[t]{2}{*}{ t-value } & \multirow[t]{2}{*}{ p-value } \\
\hline & Rivers & Lagos & & \\
\hline DBP (mmHg) & $74.84 \pm 8.46$ & $72.69 \pm 6.21$ & 2.316 & $0.021^{*}$ \\
\hline SBP (mmHg) & $113.97 \pm 10.10$ & $109.79 \pm 9.28$ & 3.471 & $0.001 *$ \\
\hline HR (bpm) & $102.97 \pm 15.68$ & $92.69 \pm 11.56$ & 5.967 & $0.001^{*}$ \\
\hline RPP (mmHg.bpm) & $11811.79 \pm 2498.98$ & $10157.40 \pm 1547.91$ & 6.330 & $0.001 *$ \\
\hline MAP (mmHg) & $87.82 \pm 7.99$ & $85.01 \pm 5.95$ & 3.179 & $0.002 *$ \\
\hline RR (bpm) & $26.35 \pm 3.37$ & $26.10 \pm 1.94$ & 0.729 & 0.467 \\
\hline FEV1 (L) & $0.95 \pm 0.26$ & $1.21 \pm 0.23$ & -8.651 & $0.001 *$ \\
\hline FVC (L) & $1.02 \pm 0.27$ & $1.31 \pm 0.24$ & -9.150 & $0.001 *$ \\
\hline $\operatorname{PEFR}(\mathrm{L} / \mathrm{s})$ & $1.40 \pm 0.46$ & $2.11 \pm 0.53$ & -11.631 & $0.001^{*}$ \\
\hline
\end{tabular}

The result of the cardiopulmonary assessment of children in the oil-spilled and gas-flared Niger-Delta community showed that the participants had a normal mean systolic blood pressure $(112.99 \pm 9.99 \mathrm{mmHg})$ and mean diastolic blood pressure $(73.63 \pm 8.41 \mathrm{mmHg})$ as compared to the predicted values in the $4^{\text {th }}$ report (prediction table not shown) (Falkner and Daniels, 2004). The HR, RPP and MAP mean results $(98.41 \pm 14.33,11187.45 \pm 2247.98$ and $86.97 \pm 8.34)$ also fell within normal ranges for age in children (Fleming et al., 2011). Gong et al (2008) observed an increase in systolic blood pressure when healthy residents were exposed to toxic flared substances like particulate matter. This study showed that the mean pulmonary function parameters $\left(\mathrm{FEV}_{1}, \mathrm{FVC}\right.$ and PEFR) of the participants in the oil-spilled and gas flared community were lower $(66 \%, 67 \%$ and $58 \%$ respectively of their predicted values). In the work by Ovuakporaye et al (2016) conducted in six gas flared communities and non-gas flared communities in the Niger-Delta it was argued that gas flaring increases mean blood pressure, HR, and RR of residents in gas flaring communities but decreases the lung functions of the residents. Other researches (Ovuakporaye et al., 2012; Webb et al., 2016) have reported that the lung functions of residents in gas-flared and oil-spilled communities were lower than those in communities not affected by oil-spillage and gas-flaring. In the Rural-Riverine Lagos community the result of the cardiopulmonary assessment of children showed that the participants had a normal mean SBP $(111.12 \pm 9.27$ $\mathrm{mmHg})$ and mean DBP $(74.05 \pm 6.85 \mathrm{mmHg})$ (prediction table not shown) (Falkner and Daniels, 2004). This result is similar to previous mean values recorded for Nigerian school children especially those in the south west (Ajayi et al., 2015). It however differs from the report by Bayat et al (2009) where lower mean values were reported for primary school 
children in Turkey. The HR, RPP and MAP mean values were also normal. This study also showed that the mean $\mathrm{FEV}_{1}$ and $\mathrm{FVC}$ and of the participants in the rural-riverine Lagos community were slightly low (77\% and $79 \%$ respectively of the predicted values), the PEFR was normal (within $80 \%$ of the predicted). This may be as a result of the effects of other air pollutants such as those from fuel combustion in vehicles and power generators on the respiratory system.

From this study, a comparison of the mean results of the cardiovascular variables showed that participants in the oil-spilled and gas-flared Niger-Delta community have SBP, HR and RPP significantly higher than those in the Rural-Riverine Lagos community. A comparison of the mean results of the pulmonary functions showed that participants in the oil-spilled and gas-flared Niger-Delta community have significantly lower $\mathrm{FEV}_{1}, \mathrm{FVC}$ and PEFR compared to those in the Rural-Riverine Lagos community. The likely explanation for the differences could be environmental factors such as those associated with flared gases and crude oil contaminated waters and crops. The study by Ovuakporaye et al (2016) concluded that the pulmonary functions of children in a non-gas flaring community should be higher than those in the flaring communities. This explains why although lower than the predicted values, the mean pulmonary values are still higher in the rural-riverine Lagos community than those in the oil-spilled and gas flared Niger-Delta community. These results also corroborate previous studies (Adienbo, 2013; Egwurugwu et al., 2013).

Conclusion: Children living in the oil-spilled and gasflared Niger-Delta community have significantly higher Systolic Blood Pressure, Heart Rate, and Rate Pressure Product and lower Forced Expiratory Volume in one second, Forced Vital Capacity and Peak Expiratory Flow Rate than children in the RuralRiverine Lagos community. Crude oil drilling companies operating in the Niger-Delta region of Nigeria and around the world should follow and adhere strictly to international best practices. There should be legislations by the government that prohibit open flaring of toxic gases and illegal oil-bunkering and all such pollution-related activities by companies and individuals.

\section{REFERENCES}

Adienbo, OM (2013). Correlation between body mass index and peak expiratory flow rate of an indigenous Nigerian population in the Niger Delta Region. Res. J. Recent Sci. 2(2): 28-32.
Ajayi, IO; Asinobi, AO; Afolabi, NB; Ayede, AI; Kadiri, S; Bamgboye, EA; Soyannwo, MAO (2015). Blood pressure pattern and hypertension related risk factors in an urban community in Southwest Nigeria: The Mokola hypertension initiative project, Ibadan, Nigeria. Inter. J. Epidemiology 44(1):140-140.

Anderson, JO; Thundiyil, JG; Stolbach, A (2012). Clearing the air: a review of the effects of particulate matter air pollution on human health. J. Med. Toxic. 8(2):166.

Bayat, M; Erdem, E; Barik, O; Bas, EM; Tas, CS (2009). Blood pressure, height, weight and body mass index of primary school students in a low socio-economic district in Turkey. Inter. Nursing Review 56:375-380.

Castro, HA; Cunha, MF; Mendonça, GA (2009). Effect of air pollution on lung function in school children in Rio de Janeiro, Brazil. Revista de saude publica 43(1):26-34.

Churg, A; Brauer, M; Del, C; Avila-Casado, M (2003). Chronic exposure to high levels of particulate air pollution and small airway remodeling. Environ. Health Perspective 111(5):714-718.

Diette, GB; Hansel, NN; Buckley, TJ (2007). Home indoor pollutant exposures among inner-city children with and without asthma. Environ. Health Perspective 15(11):1665-1669.

Egwurugwu, JN; Nwafor, A; Shinko, BC; Oluronfemi, OJ; Iwuji, SC; Nwankpa, P (2013). Effects of prolonged exposure to gas flares on the lipid profile of humans in the Niger Delta Region, Nigeria. American J. Res. Comm. 1(5): 115-145.

Ekpenyong, CE; Ettebong, EO; Akpan, EE; Samson, TK; Daniel, NE (2012). Urban city transportation mode and respiratory health effect of air pollution: a cross-sectional study among transit and non-transit workers in Nigeria. British Med. J. 2(5): 1-10.

Emam, EA (2016). Environmental Pollution and Measurement of Gas Flaring. Inter. J. Innovate. Res. Sci. Engineer. Technol. 2: 252-262.

Fleming, S; Thompson, M; Stevens, R; Heneghan, C; Plüddemann, A; Maconochie, I; Tarassenko, L; Mant, D (2011). Normal ranges of heart rate and respiratory rate in children from birth to 18 years 
of age: a systematic review of observational studies. Lancet 377(9770): 1011-1018.

Gauderman, WJ; Avol, E; Gilliland, F; Vora, H; Thomas, D; Berhane, K; McConnell, R; Kuenzli, N; Lurmann, F; Rappaport, E; Margolis, H; Bates, D; Peters, J (2004). The effect of air pollution on lung development from 10 to 18 years of age. New England J. Med. 351(11):1057-1067.

Gong, H; Linn, WS; Clark, KW; Anderson, KR; Siouta, C; Alexis, NE; Cascio, WE; Devlin, RB (2008). Exposures of healthy and asthmatic volunteers to concentrated ambient ultrafine particles in Los Angeles. Inhalational Toxicology 20(6):305-325.

Laden, F; Neas, LM; Dockery, DW; Schwartz, J (2000). Association of fine particulate matter from different sources with daily mortality in six U.S. cities. Environmental Health Perspective 108(10):941-947.

Lelieveld, J; Evans, JS; Fnais, M; Giannadaki, D; Pozzer, A (2015). The contribution of outdoor air pollution sources to premature mortality on a global scale. Nature 525(7569):367-371.

McKenzie, LM; Witter, RZ; Newman, LS; Adgate, JL (2012). Human health risk assessment of air emissions from development of unconventional natural gas resources. Sci. Total Environ. 424: 7987.

Moshammer, H; Hutter, HP; Hauck, H; Neuberger, M (2006). Low levels of air pollution induce changes of lung function in a panel of school children. European Respiratory journal 27(6): 1138-1143.

Oftedal, B; Brunekreef, B; Nystad, W; Madsen, C; Walker, S; Nafstad, P (2008). Residential outdoor air pollution and lung function in schoolchildren. Epidemiology 19(1):129-137.

Olof, L; Jonas, P (2013). Oil Contamination in Ogoniland, Niger Delta. Ambio 42(6): 685-701.

Ovuakporaye, SI; Aloamaka, CP; Ojjeh, AE; Ejebe, DE; Mordi, JC (2012). Effects of gas flaring on lung functions among residents in Gas planning community in Delta State, Nigeria. Res. J. Environ. Health Sci. 4(5):525-528.
Ovuakporaye, SI; Igweh, CJ; Aloamaka, CP (2016). Impact of Gas Flaring on Cardiopulmonary Parameters of Residents in Gas Flaring Communities in Niger Delta Nigeria. British J. Medic. Med. Res. 15(6):1-13.

Queensland Health (2012). Spirometry (Adult). Available www.health.qld.gov.au/qhpolicy/docs/gdl/qhgdl-386.pdf. Accessed on 06/03/2017.

Silva, RA; West, JJ; Zhang, Y; Anenberg, SC; Lamarque, J; Shindell, DT; Collins, WJ; Dalsoren, S; Faluvegi, G;Folberth, G; Horowitz, LW; Nagashima, T; Naik, V; Rumbold, S; Skeie, R; Sudo, K; Takemura, T; Bergmann, D; Cameron-Smith, P; Cionni, I; Doherty, RM; Eyring, V; Josse, B; MacKenzie, I A; Plummer, D; Righi, M; Stevenson, D S; Strode, S; Szopa, S; Zeng, G (2013). Global premature mortality due to anthropogenic outdoor air pollution and the contribution of past climate change. Environ. Res. Let. 8(3):34-35.

United Nations Environmental Programme (2011). Environmental assessment of Ogoniland. Nairobi. pp. 1-262.

Vedala, S; Paul, N; Mane, AB (2013). Differences in pulmonary function test among the athletic and sedentary population. Nat. J. Physiol. Pharm. Pharmacol. 3(2):118-123.

Webb, E; Hays, J; Dtrszka, L; Rodriguez, B; Cox, C; Huffling, K; Bushkin-Benient, S (2016). Potential hazards of air pollutant emissions from unconventional oil and natural gas operating on the respiratory health of children and infants. Reviews on Environmental Health 31(2):225-243.

Weinmayr, G; Romeo, E; Sario, MD (2010). Shortterm effects of (PM.sub. 10) and (NO.sub 2) on respiratory health among children with asthma or asthma-like symptoms: a systematic review and meta-analysis. Environmental Health Perspective 118(4):449-457.

World Health Organization (2012). Burden of disease from household air pollution. Geneva. 